\title{
ANALISIS TINGKAT ADOPSI INOVASI TEKNOLOGI BUDIDAYA IKAN \\ LELE SANGKURIANG PADA KELOMPOK RANCA KEMBANG DI KECAMATAN CIPANAS KABUPATEN LEBAK
}

\author{
Oleh: \\ Abdul Hanan, Walson H Sinaga, Nayu Nurmalia, Ani Leilani \\ Dosen Jurusan Penyuluhan Perikanan Sekolah Tinggi Perikanan
}

\begin{abstract}
ABSTRAK
Pengalaman usaha bidang perikanan pada responden berhubungan erat sapai pada pada tahap mencoba inovasi, sedangkan tingkat keinovatifan responden berhubungan erat sampai pada tingkat menerapkan inovasi yang dianjurkan. Umur responden. Lama pendidikan, dan tingkat kekosmopolitan tidak berhubungan erat dengan tingkat adopsi inovasi ikan lele sangkuriang.Peranan penyuluh perikanan sangat berhubungan erat sampai tahap mencoba dan berhubungan erat pada tahap menerapkan para responden terkait inovasi yang dianjurkan yaitu budidaya ikan lele sangkuriang pada kolam terpal. Sedangkan peranan ketua kelompok sangat berhubungnha erat sampai tahap menilai inovasi yang dianjurkan bagi para responden. Peranan dinas perikanan dan peranan media massa kurang berhubungan erat dengan tingkat adopsi budidaya ikan lele sangkuriang pada kolam terpal.

Karakteristik inovasi berupa keuntungan relatif budidaya ikan lele sangkuriang dibandingkan inovasi lainnya (budidaya pertanian), keselarasan dengan kondisi lingkungan responden berhubungan sangat erat sampai pada tahap minat responden pada inovasi tersebut. Budidaya ikan lele sangkuriang dianggap tidak rumit diterapkan/dipraktekan oleh responden sangat berhubungan erat bagi responden untuk berminat dan sampai menghitung untung rugi dari inovasi tersebut (tahap minat). Budidaya ikan lele sangkuriang dengan karakteristik yang mudah diamati hasilnya oleh responden berhubungan erat pada tahap minat pada responden dan berhubungan sangat erat pada tahap mencoba. Namun demikian berdasarkan hasil analisis ciri inovasi teknologi budidaya ikan lele sangkuriang pada kolam terpal dengan ciri yang mudah dan cepat diamati yang berhubungan sangat erat kecepatan adopsi sampai tahap mencoba, sedangkan ciri inovasi lainnya baru sampai rata-rata pada tahap mminat.
\end{abstract}

Kata kunci : 


\section{PENDAHULUAN}

\section{Latar Belakang}

Difusi inovasi pada dasarnya adalah peningkatan kualitas sumberdaya manusia perikanan melalui upaya peningkatan perubahan pengetahuan dan keterampilan serta pemberian motivasi melalui kegiatan penyuluhan periknan. Penyuluhan perikanan adalah pendidikan non formal yang ditujukan kepada masyarakat khususnya nelayan, pembudidaya dan pengolah hasil perikanan beserta keluarganya untuk meningkatkan pengetahuan, keterampilan, sikap dan motivasi dalam bidang perikanan. Kegiatan penyuluhan diharapkan mampu mendorong terwujudnya masyarakat perikanan yang lebih baik (beter farming), menuju kehidupan yang lebih layak (beter community), berusaha yang lebih menguntungkan (beter bussines), dan hidup lebih sejahtera (beter living).

Kecamatan Cipanas Kabupaten Pandeglang merupakan suatu wilayah yang telah dilakukan difusi inovasi budidaya ikan lele pada kolam terpal. Pada awal kegiatan yang menjadi sasaran difusi inovasi budidaya ikan lele sangkuriang sebanyak 25 orang penduduk yang mewakili tiap desa. Untuk melihat sampai sejauh mana tingkat adopsi ke 25 orang tersebut dan maka diperlukan pengkajian tingkat adopsi inovasi sampai dua tahun terakhir ini.

Kecepatan adopsi suatu inovasi yang disampaikan kepada masyarakat di Kecamatan Cipanas kabupaten Pandeglang merupakan fenomena yang menarik, dikarenakan inovasi budidaya ikan lele sangkuriang pada kolam terpal untuk pertama kali diperkenalkan dan diberikan percontohan oleh STP Jurusan Penyuluhan Perikanan Bogor pada tahun 2011. Satu tahun sejak inovasi tersebut didifusikan tingkat adopsinya dari masing-masing pelaku utama perikanan (pumakan) berbeda tingkatakannya. Hal-hal yang mempengaruhi kecepatan adopsi para pumakan diantaranya karakteristik internal pumakan, karanteristik eksternal pumakan serta karakteristik dari inovasi yang ditawarkan.

\section{Tujuan dan Manfaat Penelitian}

Adapun tujuan penelitian ini adalah:

a) Menjelaskan hubungan karakteristik internal pumakan dengan tingkat adopsi budidaya ikan lele kolam terpal

b) Menjelaskan hubungan karakteristik eksternal pumakan dengan tingkat adopsi budidaya ikan lele kolam terpal

c) Menjelaskan hubungan karakteristik inovasi dengan tingkat adopsi budidaya ikan lele kolam terpal

Penelitian ini diharapkan dapat memberikan manfaat antara lain:

a) Memberikan kontribusi bagi pengembangan ilmu dan teknologi terutama yang berkaitan dengan difusi inovasi teknologi

b) Memberikan masukan dan saran bagi program penyuluhan terkait dengan materi dan metode penyuluhan.

\section{KERANGKA PIKIR DAN HIPOTESIS}

Terdapat beberapa faktor yang berhubungan dengan tingkat adopsi pada 
sistem sosial suatu kelompok. Faktorfaktor tersebut yaitu faktor internal pumakan, faktor ekternal pumakan dan karakteristik inovasi. Berdasarkan hal tersebut disusn suatu kerangka pikir seperti pada Gambar 1.

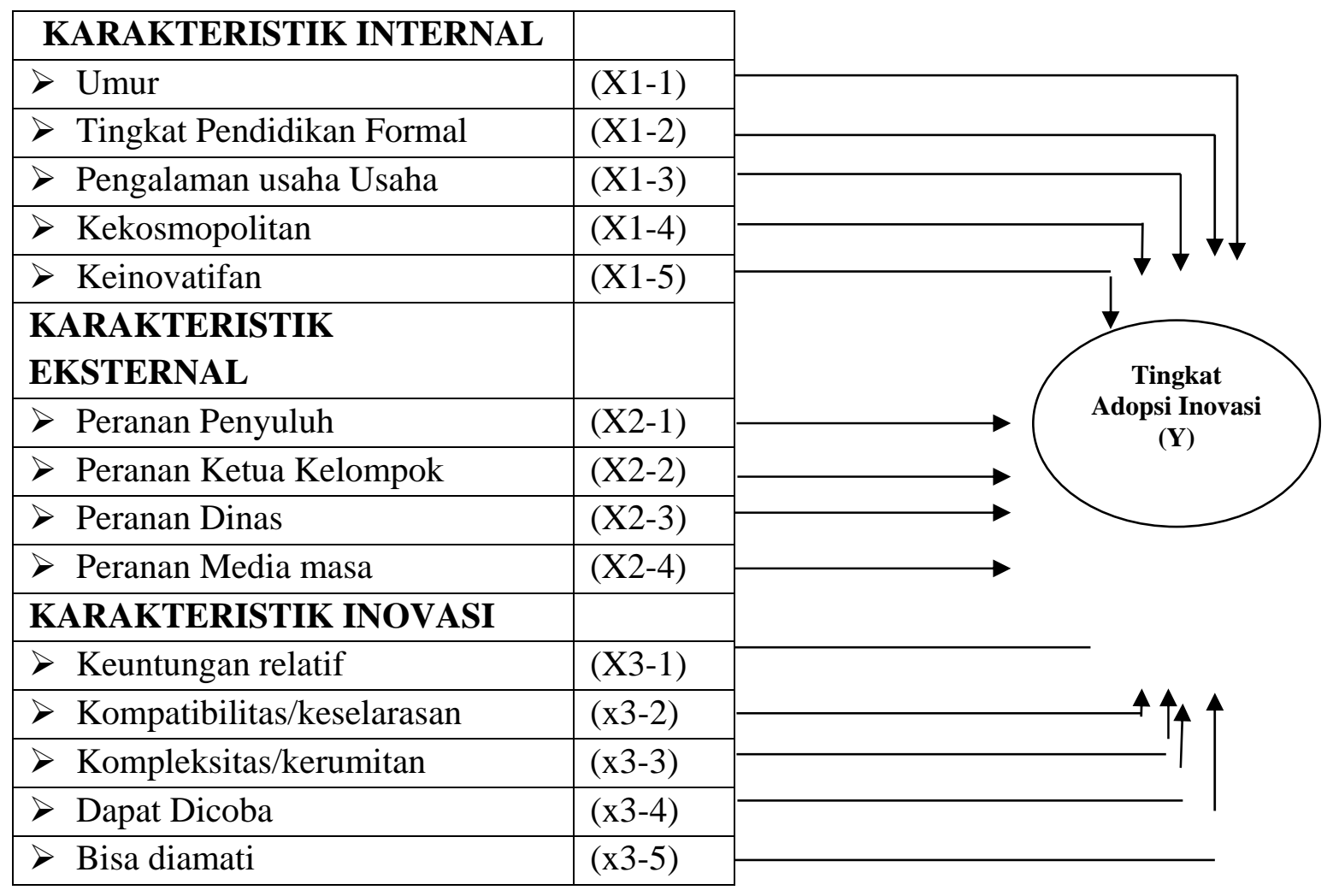

Hipotesis berdasarkan gambar di atas

1. Terdapat hubungan yang nyata antara karakteristik internal dengan tingkat adopsi inovasi

2. Terdapat hubungan yang nyata antara karakteristik eksternal dengan tingkat adopsi inovasi

3. Terdapat hubungan yang nyata antara karakteristik inovasi dengan tingkat adopsi inovasi.

\section{METODE PENELITIAN}

Penelitian ini dilakukan di Kelompok Ranca Kembang Kecamatan Cipanas, Kabupaten Lebak Provinsi Banten yang dilakukan selama 4 minggu pada Bulan Desember 2011. Sampel pada penelitian ini adalah 25 orang pumakan yang telah mendapatkan penyuluhan budidaya ikan lele sangkuriang.

Data yang dikumpulkan terdiri dari data primer dan data sekunder. Data primer dikumpulkan dengan wawancara kepada pelaku utama pembudidaya ikan lele menggunakan daftar pertanyaan (kuisioner) yang telah disiapkan, dan dilakukan juga wawancara mendalam (indepth interview) dengan ketua kelompok, Penyuluh Perikanan, dan Kepala Desa. Data sekunder dikumpulkan dari Badan Pelaksana Penyuluhan kabupaten dan Balai Penyuluhan di Kecamatan. 


\section{ANALISA DATA}

Analisa data dilakukan secara deskriftif, analisa kualitatif dilakukan untuk semua tujuan penelitian, analisa kuantitatif dilakukan untuk menguji hipotesis yang diajukan.

karakteristik internal dan karakteristik eksternal serta karakteristik inovasi diukur dengan menggunakan distribusi frekuensi dan nilai tengah. Untuk mengetahui hubungan antar peubah dilakukan analisis hubungan dengan koefisien korelasi Spearman, sebagai uji korelasi bagi data non parametrik.

\section{HASIL DAN PEMBAHASAN}

\section{Gambaran Umum Lokasi}

Lokasi penelitian merupakan Kegiatan adalah Lokasi yang memiliki kegiatan teknis dan sosial ekonomi di bidang perikanan yang berada di Kecamatan Cipanas Kabupaten Lebak Provinsi Banten. Kondisi lokasi tersebut memiliki peluang dalam rangka mendukung pengembangan usaha yakni memiliki Sumberdaya alam dan irigasi teknis yang cukup baik, kolam untuk kegiatan budidaya berkisar 30 ha dan 350 ha sawah yang merupakan irigasi teknis. Peluang pasar masih cerah, hal ini ditandai dengan pemenuhan kebutuhan pasar di lokasi tersebut masih disuplai atau dipenuhi dari daerah luar. Lokasi termasuk strategis, dekat dengan
Rangkasbitung, Bogor dan Jakarta. Prasarana jalan cukup memadai dengan fasilitas aspal sampai ke desa-desa. Sumberdaya Manusia yang berpendidikan, terdapat kelompokkelompok pelaku utama dan sudah terdapat UPR serta CPIB dalam rangka mendukung keiatan usaha yang ada dilokasi tersebut. Namun beberapa kelemahan yang terdapat dilokasi tersebut adalah mental usaha para pembudidaya masih rendah dan kegiatan usaha belum berorientasi kepada bisnis/usaha, masyarakat cenderung cepat bosan dengan kegiatan yang dijalankan dan ketika mengalami suatu kegagalan pembudidaya cenderung tidak memiliki sebuah motivasi lagi untuk melanjutkan kembali kegiatan usahanya. Dukungan pemerintah dalam hal penjaminan terhadap kegiatan usaha masih kurang sehinga para investorinvestor jarang sekali bahkan tidak ada yang berani masuk untuk menanam investasi di lokasi tersebut. Upaya yang dilakukan dalam trangka mengatasi permasalah tersebut STP Jurluhkan bogor melakukan kegiatan antara lain:

\section{Karakteristik Internal Responden}

Karakteriktik internal responden penelitian yaitu umur, lama pendidikan, lama pengalaman usaha, tingkat kekosmopolitan dan tingkat keinovatifan yang dianalisis dengan pengkatagorian, pedrsentase, interval dan rata-rata , seperti pada Tabel 1. 
Tabel 1. Sebaran Karakteriktik Internal

\begin{tabular}{|c|c|c|c|c|c|}
\hline NO & KARAKTERISTIK & KATAGORI & $\begin{array}{l}\text { PERSENTASE } \\
(\mathrm{N}=30)\end{array}$ & INTERVAL & $\begin{array}{l}\text { RATA- } \\
\text { RATA }\end{array}$ \\
\hline 1 & UMUR & $\begin{array}{ll}\text { Muda } & (<30,5 \\
\text { th) } & \\
\text { Sedang } & (30,5- \\
54,1 \text { th }) & \\
\text { Tua } & \\
(>54,1 \text { th }) & \end{array}$ & $\begin{array}{l}23,3 \\
63,3 \\
13,4\end{array}$ & $24-67$ th & 42,3 th \\
\hline 2 & LAMA PENDIDIKAN & $\begin{array}{l}\text { Rendah } \\
(<4,5 \text { th }) \\
\text { Sedang } \\
7,9 \text { th) } \\
\text { Tinggi } \\
\text { (>7,9th) }\end{array}$ & $\begin{array}{l}10,0 \\
63,4 \\
26,6\end{array}$ & 3-12 TH & $7,8 \mathrm{TH}$ \\
\hline 3 & $\begin{array}{l}\text { PENGALAMAN } \\
\text { USAHA }\end{array}$ & $\begin{array}{lr}\text { Rendah } & (<1,1 \\
\text { bln) } & \\
\text { Sedang } & (1-3,7 \\
\text { bln) }) & \\
\text { Tinggi } & (>3,7 \\
\text { bln) }) & \end{array}$ & $\begin{array}{l}40,0 \\
50,0 \\
10,0\end{array}$ & 1-7 bulan & $\begin{array}{l}52,2 \\
\text { bulan }\end{array}$ \\
\hline 4 & $\begin{array}{l}\text { TINGKAT } \\
\text { KEKOSMOPOLITRAN }\end{array}$ & $\begin{array}{lr}\text { Rendah } & (<1,5) \\
\text { Sedang } & (1,5- \\
2,3) & \\
\text { Tinggi } & \\
(>2,3) & \end{array}$ & $\begin{array}{l}13,3 \\
73,4 \\
13,3\end{array}$ & $1-2,3$ & 1,9 \\
\hline 5 & $\begin{array}{l}\text { TINGKAT } \\
\text { KEINOVATIFAN }\end{array}$ & $\begin{array}{lr}\text { Rendah } & (<1,8) \\
\text { Sedang } & (1,8- \\
2,2) & \\
\text { Tinggi } & \\
(>2,3) & \end{array}$ & $\begin{array}{r}6,7 \\
80,0 \\
13,3\end{array}$ & $1-2,3$ & 2,0 \\
\hline
\end{tabular}

Ciri-ciri pelaku utama perikanan berkaitan erat dengan keputusan adopsi inovasi. Ciri-ciri dimaksud meliputi: (Roger \& Soemaker,1987): karakteristik sosio ekonomik antara lain: pendidikan, mobilitas sosial, ukuran usaha, orientasi usaha dan sikap terhadap inovasi; (2) varibel personalitas antara lain: motivasi meningkatnya taraf hidup serta aspirasi terhadap pendidikan dan pekerjaan; (3) perilaku komunikasi antara lain: partisipasi sosial, komunikasi interpersonal dengan anggota dan bukan anggota sistem sosial, kontak dengan agen pembaharu.
Pada Tabel 1 memperlihatkan bahwa umur responden 63,3\% pada kisaran umur sedang (30,5-54,1 tahun) dengan rata-rata 42,3 tahun, Kisaran umur tersebut merupakan usia produkstif dalam berusaha, dalam arti dari segi fisik punya kemampuan untuk melakukan usaha perikanan. Dari segi pendidikan hanya 43,3 \% para responden yang tamat Sekolah dasar, dan sebanyak 10\% mengikuti pendidikan di bawah 5 tahun.

Pengalaman berusaha pada katagori sedang sekitar 50\% punya pengalaman 1-3,7 bulan, lamanya pengalaman tersebut berarti para 
responden belum melakukan panen. Namun demikian sekitar 10\% responden pengalaman usaha tergolong tinggi berarti ada yang sudah melakukan usaha budidaya ikan lele sampai panen.

Tingkat kekosmopolitan adalah kinerja pelaku utama perikanan dalam mencari informasi ke luar lingkungannnya, baik ke sesama pelaku utama perikanan, ke penyuluh dan kelembagaan penyuluhan perikanan maupun intansi dan lembaga lain yang terkait dengan usaha yang akan dijalankan. Hasil penelitian menunjukkan bahwa sebanyak 86,7\% responden termasuk yang tingkat kekosmopolitannya cukup, namun tidak ada responden dengan tingkat katagori yang tingkat kekosmopolitannya tinggi. Hal tersebut menunjukkan para responden cukup baik dan sering mencari informasi untuk keputusan adopsi inovasi yang telah didifusikan.

Keinovafan responden juga sebanyak 80\% katagorinya cukup, artinya para responden cukup baik dalam menerima dan mau mengaplikasikan inovasi yang diterimanya. Hasil pengamtan di lapangan menunjukkan bahwa para responden cukup aktif mengikuti kegiatan usaha yang dikelola oleh kelompok, dan menyempatkan untuk hadir pada waktu ada kegiatan penyuluhan. Namun demikian tingkat adopsi di tingkat individu masih tergolong rendah.

Sehubungan dengan data tersebut dapat dijelaskan bawa ada korelasi antara umur, pendidikan, tingkat kekosmopolitan, dan keinovatifan dengan kecepatan adopsi. Roger dan Shoemaker (1987 ) menjelaskan berdasarkan kecepatan adopsi terhadap suatu inovasi dikenal 5 (lima) golongan adopter yaitu (1) Inovator disebut juga golongan perintis atau pelapor. Golongan perintis ini jumlahnya tidak banyak dalam masyaraka, dan dilokasi penelitian baru terdapat 2 orang. Karakteristik golongan ini antara lain: gemar, mencoba, inovasi dan rata-rata pada masyarakatnya pada umumnya berpartisipasi aktif dalam penyebarluasan inovasi. (2) Early Adopter dsebut juga golongan pengetrap dini.

Golongan ini mempunyai tingkat pendidikan yang tinggi, gemar membaca buku, suka mendengar radio, memiliki faktor produksi non lahan yang relatif komplit. Hasil penelitian menunjukkan ada sekitar 26,6 \% (sekitar 5 orang) termasuk katagori early adopter. (3) Early Mayority dsebut juga golongan Pengetrap awal. Golongan ini pada umumnya mempunyai tingkat pendidikan rata-rata seperti anggota masyarakat lainnya, dapat menerima inovasi selama inovasi tersebut memberikan keuntungan kepadanya hasil penelitian ada sekitar $63,3 \%$ di lokasi penelitian. (4)n Late Mayority disebut juga golongan Pengetrap akhir. Golongan ini ada sekitar 13,4\% pada umumnya berusia lanjut dan memilki tingkat pendidikan rendah, status sosial ekonominya sangat rendah dan lambat menerapkan inovasi. (5) Laggard dseburt juga Golongan Penolak Golongan penolak ini pada umumnya usia lanjut, jumlahnya sangat sedikit dan tingkat pendidikannya sangat rendah bahkan buta huruf, status sosial eknominya sangat rendah, tidak suka terhadap perubahan-perubahan. Pada penelitian termasuk yang tingkat 
keinovatifannya rendah yaitu sekitar $6,3 \%$.

Berdasarkan penjelasaan dari

Roger dan Shomaker tersebut yang dupekuat oleh van Den Ban

(1985)

Tabel 2. Karkteristik Sosial Ekonomi pada Berbagai Kategori Adopter.

\begin{tabular}{|c|c|c|c|c|c|}
\hline \hline Variabel & Inovator & Early Adaptor & $\begin{array}{c}\text { Early } \\
\text { Mayority }\end{array}$ & $\begin{array}{c}\text { Late } \\
\text { Mayority }\end{array}$ & Laggard \\
\hline Umur & Setengah Umur & Muda & $\begin{array}{c}\text { Setangah } \\
\text { Umur tua }\end{array}$ & $\begin{array}{c}\text { Muda sampai } \\
\text { tua }\end{array}$ & Tua \\
\hline Pendidikan & Tinggi & Tinggi & Sedang & Rendah & $\begin{array}{c}\text { Rendah } \\
\text { Sekali }\end{array}$ \\
\hline Ekonomi & Baik & Baik & $\begin{array}{c}\text { Sedang } \\
\text { sampai baik }\end{array}$ & Kurang & $\begin{array}{c}\text { Kurang } \\
\text { sekali }\end{array}$ \\
\hline Status Sosial & Tinggi & Sedang & $\begin{array}{c}\text { Sedang } \\
\text { sampai baik }\end{array}$ & Rendah & $\begin{array}{c}\text { Paling } \\
\text { rendah }\end{array}$ \\
\hline $\begin{array}{c}\text { Pola } \\
\text { Hubungan }\end{array}$ & Kosmopolit & Kosmopolit & $\begin{array}{c}\text { Cendrung } \\
\text { Lokalita }\end{array}$ & Lokalita & $\begin{array}{c}\text { Sangat } \\
\text { lokalita }\end{array}$ \\
\hline & & & & & \\
\hline \hline
\end{tabular}

\section{Karakteristik Eksternal Responden}

Karakteriktik eksternal responden penelitian yaitu peranan penyuluh, peranan ketua kelompok, peranan dinas teknis dan peranan media masa, seperti pada Tabel 3.

Tabel 3. Sebaran Karakteriktik External

\begin{tabular}{|c|c|c|c|c|c|}
\hline NO & KARAKTERISTIK & KATAGORI & $\begin{array}{l}\text { PERSENTASE } \\
(\mathrm{N}=30)\end{array}$ & INTERVAL & $\begin{array}{l}\text { RATA- } \\
\text { RATA }\end{array}$ \\
\hline 1 & Peranan Penyuluh & $\begin{array}{lr}\text { Rendah } & (<0,83) \\
\text { Sedang( }(0,83-2,27) \\
\text { Tinggi } \quad(>2,27)\end{array}$ & $\begin{array}{c}0 \\
90 \\
10\end{array}$ & $1,6-2,9$ & 2,05 \\
\hline 2 & $\begin{array}{r}\text { Peranan Ketua } \\
\text { Kelompok }\end{array}$ & $\begin{array}{lr}\text { Rendah } \quad(<1,85) \\
\text { Sedang(1,85- } 2,33) \\
\text { Tinggi } \quad(>2,33)\end{array}$ & $\begin{array}{c}6,6 \\
83,4 \\
10\end{array}$ & $1,7-2,9$ & 2,09 \\
\hline 3 & Peranan Dinas & $\begin{array}{l}\text { Rendah } \quad(<1,1) \\
\text { Sedang }(1,1-2,0)) \\
\text { Tinggi } \quad(>2,0))\end{array}$ & $\begin{array}{c}50 \\
46,7 \\
13,3\end{array}$ & $1-2,4$ & 1,54 \\
\hline 4 & Peranan Media masa & $\begin{array}{l}\text { Rendah } \quad(<1,08) \\
\text { Sedang( }(1,08-1,64) \\
\text { Tinggi } \quad(>1,64)\end{array}$ & $\begin{array}{l}16,6 \\
66,8 \\
16,6\end{array}$ & $1-2$ & 1,36 \\
\hline
\end{tabular}

Pada Tabel 3 memperlihatkan hanya $10 \%$ yang menyebutkan peranan penyuluh tinggi. Terkait peranan penyuluh Hariandi (2011) menjelaskan faktor penyuluhan tidak berpengaruh terhadap keberhasilan kelompok sebagai unit belajar karena inovasi dari penyuluh diperbincangkan dahulu oleh para anggota kelompok dalam proses interakasi. Namun demkian sebanyak 
90\% responden menyatakan peranan penyuluh perikanan cukup tinggi, demikian pula peranan ketua kelompok dinilai tinggi dalam mendifusikan budidaya ikan lele sangkuriang yang diakui oleh 83,4 responden, hal tersebut juga dijelaskan oleh hariadi (2011) bahwa di dalam sebuah kelompok, pelaku utama yang lebih maju dan lebih dulu memahami inovasi merupakan sumber informasi atau model bagi bagi pelaku utama lain dalam proses social learning. Peranan dinas perikanan sebanyak 50\% responden mengatakan peranan dinas perikanan dalam proses adopsi inovasi ikan lele sangkuriang adalah rendah, dan hanya $46,7 \%$ responden yang mengakui peranan dinas perikanan sedang. Terkait kelembnagaan teknis Sumardjo dalam Anonimous (2003) menyebutkan bahwa Pemerindah daerah sudah ada yang komitmen dalam penyebaran inovasi, namun kelembagaan tersebut kurang didukung inovasi, Ilmu pengetahun dan teknologi (iptek). Selanjutnya disebutkan keberpihakan dinas teknis lebih pada kepentingan pemerintah dan kurang komitmen serta keberpihakan pada pelaku utama. Peranan media masa diakui sedang oleh sebanyak 66,6\% respoinden, dan yang menyatakan peranan rendah dan tinggi sama diakui oleh 16,6\% responden. Dengan demikian karanteristik ekternal pelaku utama perikanan yaitu peranan penyuluh perikanan, peranan ketua kelompok, peranan dinas perikanan dan peranan media masa semua responden mengakui baru berperan cukup/sedang dalam mendifusikan inovasi budidaya ikan lele sangkuriang.

\section{Karakteristik Inovasi}

Inovasi adalah gagasan, ide, teknologi baru atau yang dianggap baru oleh suatu sistem sosial. Menurut Van den ban \& Hawkins (1988) berbagai macam inovasi yang perlu diperhatikan oleh agen penyulouhan yaitu: 1) Metode baru untuk membantu keputusan mengenai pengelolaan, seperti pengujian tanah/air. 2) Siitem Usaha perikanan baru, seperti budidaya ikan komersil 3) Organisasi sosial baru seperti kelompok atau gabungan kelompok/asosiasi.

Tabel 4. Sebaran Karakteriktik Inovasi

\begin{tabular}{|c|c|c|c|c|c|}
\hline NO & KARAKTERISTIK & KATAGORI & $\begin{array}{c}\text { PERSENTASE } \\
(\mathrm{N}=30)\end{array}$ & $\begin{array}{l}\text { INTER } \\
\text { VAL }\end{array}$ & $\begin{array}{l}\text { RERA } \\
\text { TA }\end{array}$ \\
\hline 1 & Keuntungan relatif & $\begin{array}{lc}\text { Rendah } & (<1,7) \\
\text { Sedang } & (1,7-2,5) \\
\text { Tinggi } & (>2,5)\end{array}$ & $\begin{array}{c}13,3 \\
86,7 \\
0\end{array}$ & $1-3$ & 2,1 \\
\hline 2 & Kompatibilitas/keselarasan & $\begin{array}{lc}\text { Rendah } & (<1,57) \\
\text { Sedang } & (1,57-2,43) \\
\text { Tinggi } & (>2,43)\end{array}$ & $\begin{array}{l}23,3 \\
46,7 \\
30,0\end{array}$ & $1-2,5$ & 2,0 \\
\hline 3 & Kompleksitas & $\begin{array}{lc}\text { Rendah } & (<1,80) \\
\text { Sedang } & (1,80-2,9) \\
\text { Tinggi } & (>2,9))\end{array}$ & $\begin{array}{l}13,3 \\
53,4 \\
33,3\end{array}$ & $1-3$ & 2,22 \\
\hline 4 & Dapat Dicoba & $\begin{array}{ll}\text { Rendah } & (<1,74) \\
\text { Sedang } & (1,74-2,7) \\
\text { Tinggi } & (>2,7)\end{array}$ & $\begin{array}{l}13,3 \\
70,1 \\
16,6\end{array}$ & $1-3$ & 2,22 \\
\hline & Bisa diamati & $\begin{array}{lc}\text { Rendah } & (<1,79) \\
\text { Sedang } & (1,79-2,81) \\
\text { Tinggi } & (>2,81)\end{array}$ & $\begin{array}{r}3,3 \\
66,7 \\
30,0\end{array}$ & $1-3$ & 2,3 \\
\hline
\end{tabular}


Berdasarkan hasil analisis seperti pada Tabel 4, menunjukkan bahwa karakteristik inovasi yang berhubungan dengan tingkat difusi inovasi budidaya ikan lele sangkuriang ciri inovasi dengan keuntungan relatif diakui berperan sedang oleh $86,7 \%$ responden. Terkait dengan cirri tersebut van Den Ban dan Hawkins (1985) menjelaskan motivasi pelaku utama mengadopsi suatu inovasi pada cirri keuntungan relatif dipengaruhi oleh pemberian insetif (penyediaan benih dan saprokan) dan hasil penelitian menunjukkan kurangnya penyediaan fasilitas tersebut kecepatan adopsi rendah. Sedangkan untuk ciri inovasi lele sangkuriang yang selaras dengan budaya dan kondisi lingkungan setempat, budidaya ikan lele sangkuriang tidak rumit, serta hasilnya bisa cepat diamati dianggap berperan tinggi oleh sebanyak 30 - 33,3\% para responden, dan responden yang menganggap ciri inovasi tersebut berperan sedang diakui oleh sebanyak $46,7-66,7 \%$ responden.

Tabel 5. Sebaran Tingkat Adopsi

\begin{tabular}{|c|c|c|c|c|c|}
\hline NO & KARAKTERISTIK & KATAGORI & $\begin{array}{l}\text { PERSEN } \\
\text { TASE } \\
(\mathbf{N}=\mathbf{3 0})\end{array}$ & $\begin{array}{l}\text { INTER } \\
\text { VAL }\end{array}$ & $\begin{array}{l}\text { RERA } \\
\text { TA }\end{array}$ \\
\hline 1 & Tingkat Sadar & $\begin{array}{lr}\text { Lambat } & (<1 \text { hari }) \\
\text { Sedang } & (1-3 \text { hari }) \\
\text { Cepat } & (>3 \text { hari })\end{array}$ & $\begin{array}{c}43,3 \\
56,7 \\
0\end{array}$ & $\begin{array}{l}1-3 \\
\text { hari }\end{array}$ & 2 hari \\
\hline 2 & Tingkat Minat & $\begin{array}{lr}\text { Lambat } & (<2 \text { hari }) \\
\text { Sedang } & (2-7 \text { hari }) \\
\text { Cepat } & (>7 \text { hari })\end{array}$ & $\begin{array}{c}30 \\
70 \\
0\end{array}$ & $\begin{array}{l}1-7 \\
\text { hari }\end{array}$ & 4 \\
\hline 3 & Tingkat Menilai & $\begin{array}{lr}\text { Lambat } & (<5 \text { hari }) \\
\text { Sedang } & (5-30 \text { hari }) \\
\text { Cepat } & (>30 \text { hari })\end{array}$ & $\begin{array}{c}20 \\
80 \\
0\end{array}$ & $\begin{array}{c}3-30 \\
\text { hari }\end{array}$ & 17 hari \\
\hline 4 & Tingkat Mencoba & $\begin{array}{lr}\text { Lambat } & (<6 \text { hari }) \\
\text { Sedang } & (6-16 \text { hari }) \\
\text { Cepat } & (>16 \text { hari })\end{array}$ & $\begin{array}{c}80 \\
3,3 \\
16,7\end{array}$ & $\begin{array}{c}0-30 \\
\text { hari }\end{array}$ & 5 hari \\
\hline & Tingkar menerapkan & $\begin{array}{lr}\text { Lambat } & (<6 \text { hari }) \\
\text { Sedang } & (6-16 \text { hari }) \\
\text { Cepat } & (>16 \text { hari })\end{array}$ & $\begin{array}{c}86,7 \\
0 \\
13,3\end{array}$ & $\begin{array}{c}0-30 \\
\text { hari }\end{array}$ & 4 hari \\
\hline
\end{tabular}

Tingkat adopsi inovasi budidaya ikan lele sangkuriang oleh para responden, untuk tingkat kesadaran termasuk lambat yaitu 43,3\% responden, katagori tingkat adopsi sedang pada $56,7 \%$ responden dan tidak ada responden dengan tingkat keasadaran cepat. Demikian pula untuk tingkat minat, hanya tidak ada responden yang tergolong cepat sebanyak 70\% tergolong sedang, dan sebanyak 30\% responden tergolong lambat, sedangkan untuk tahap menilai juga tidak ada katagori responden yang cepat, hanya 20\% tergolong lambat, dan 70\% tergolong sedang. Responden pada tahap mencoba dan menerapkan keduanya termasuk tingkat adopsi yang lambat yaitu sebanyak 80\% responden pada 
tahap mencoba, dan $86,7 \%$ pada tahap menerapkan)

Tabel 6. Tabulasi Silang karakteristik internal dengan Karakteristik Pribadi

\begin{tabular}{|c|c|c|c|c|c|c|c|c|c|c|}
\hline \multirow{2}{*}{\multicolumn{2}{|c|}{ Karakteristik }} & \multicolumn{3}{|c|}{ Umur } & \multicolumn{3}{|c|}{ Pendidikan } & \multicolumn{3}{|c|}{ Pengalaman } \\
\hline & & $\mathbf{R}$ & $S$ & $\mathbf{T}$ & $\mathbf{R}$ & S & $\mathbf{T}$ & $\mathbf{R}$ & S & $\mathbf{T}$ \\
\hline \multirow{4}{*}{ Kekosmopolitan } & $\mathrm{R}$ & 0 & 13,3 & 0 & 0 & 13,3 & 0 & 6,7 & 13,3 & 0 \\
\hline & S & 93,3 & 80,0 & 100 & 100 & 80 & 96,7 & 90 & 73,4 & 100 \\
\hline & $\mathrm{T}$ & 6,7 & 6,7 & 0 & 0 & 6,7 & 3,3 & 3,3 & 13,3 & 0 \\
\hline & & 100 & 100 & 100 & 100 & 100 & 100 & 100 & 100 & 100 \\
\hline \multirow{4}{*}{ Keinovatifan } & & 0 & 6,7 & 0 & 0 & 13,3 & 0 & 0 & 6,7 & 6,7 \\
\hline & $\mathrm{S}$ & 96,7 & 86,6 & 100 & 93,3 & 76,7 & 96,7 & 100 & 83,3 & 96,6 \\
\hline & & 3,3 & 6,7 & 0 & 6,7 & 10 & 3,3 & 0 & 10 & 6,7 \\
\hline & & 100 & 100 & 100 & 100 & 100 & 100 & 100 & 100 & 100 \\
\hline
\end{tabular}

Ket: $\mathbf{R}=$ Rendah; $\mathrm{S}=$ Sedang; $\mathrm{T}=$ Tinggi

Tabel 6, menunjukkan bahwa usia responden pada katagori umur muda (rendah), dan sedang tingkat kekosmopiltan pada katagori sedang. Sedangkan responden pada katagori umut tua $100 \%$ tingkat kekosmopolitan pada katagori sedang. Pada Tingkat pendidikan responden yang menyelesaikan lama pendidikan dengan katagori rendah $100 \%$ tingkat kekosmopolitannya sedang, dan pada katagori tingkat pendidikan yang tinggi tidak ada yang katagori tingkat kekosmopolitannya rendah. Sedangkan pada tingkat pengalaman responden dengan tingkat pengalaman yang tinggi katagori tingkat kekosmopolitnnya $100 \%$ sedang.

Analisis silang tingkat keinovatifan responden memperlihatkan bahwa responden dengan katagori muda dan usia sedang, tingkat keinovatifannya mayoritas pada katagori sedang, dan pada usia tua $100 \%$ tingkat keinovatifannya juga dengan katagori sedang.

Tingkat pendidikan responden katagori rendah, sedang dan tinggi tingkat keinovatifan responden tergolong sedang interval $\quad 76,7 \%$ samnpai $\quad 96,7 \%$ responden.

Pengalaman responden dengan katagori rendah, $100 \%$ tingkat keinovatifannya sedang, dan pada pengalaman yang sedang dan tinggi katagori tingkat keinovatifannya masing-masing sebesar 83,3\% dan 96,6\%.

Hasil analisis korelasi Rank Spearman antara karakteristik internal para responden dengan tingkat adopsi inovasi budidaya ikan lele sangfkuriang yang disampaikan sepeti pada Tabel 3.

Tabel 7. Nilai Korelasi karakteristik Internal dengan Tingkat Adopsi

\begin{tabular}{|l|c|c|c|c|c|}
\hline \multicolumn{1}{|c|}{ TK. Adopsi } & Sadar & Minat & Menilai & Mencoba & Menerapkan \\
Karakteristik Responden & & & & & \\
\hline Umur & 0,24 & 0,132 & 0,146 & $-0,155$ & $-0,25$ \\
\hline Pendidikan & $-0,075$ & $-0,291$ & 0,101 & 0,099 & $-0,048$ \\
\hline Pengalaman usaha & 0,139 & -0.32 & 0,129 & $\mathbf{0 , 4 0 4}$ & 0,256 \\
\hline Tingkat kekosmopolitan & 0,295 & 0,084 & $-0,026$ & 0,003 & 0,189 \\
\hline Tingkat Keinovatifan & 0,04 & 0,095 & $-0,346$ & 0,147 & $\mathbf{0 , 3 9 5}$ \\
\hline
\end{tabular}


Ket; $\quad *=$ menunjukkan nyata taraf kepercayaan 0,05

$* *=$ menunjukkan nyata pada taraf nyata 0,01

Hasil uji korelasi dengan dianjurkan. Sedangkan karakteristik menggunakan metode Rank Spearman, internal responden lainna yaitu umur seperti pada Tabel 7 menunjukkan responden. Lama pendidikan, dan bahwa pengalaman usaha bidang tingkat kekosmopolitan tidak perikanan pada responden berhubungan berhubungan erat dengan tingkat adopsi erat sapai pada pada tahap mencoba inovasi, sedangkan tingkat keinovatifan responden berhubungan erat sampai inovasi ikan lele sangkuriang.

Hasil analisis nilai korelasi antara pada tingkat menerapkan inovasi yang pemimpin opini dijelaskan pada Tabel 8. Tabel 8. Nilai Korelasi Karakteristik Eksternal dengan Tingkat Adopsi

\begin{tabular}{|l|c|c|c|c|c|}
\hline \multicolumn{1}{|c|}{ Tk. Adopsi } & Sadar & Minat & Menilai & Mencoba & Menerapkan \\
Karakteristik Eksternał & & & & & \\
\hline Peranan Penyuluh & $-0,069$ & $-0,275$ & $-0,29$ & $\mathbf{0 , 4 9 9 * *}$ & $\mathbf{0 , 3 6 7 *}$ \\
\hline Peranan Ketua Kelompok & $-0,249$ & $-0,331$ & $\mathbf{- 0 , 5 1 9 * *}$ & 0,303 & 0,339 \\
\hline Peranan Dinas & 0,043 & 0,058 & 0,090 & $-0,206$ & $-0,068$ \\
\hline Peranan Media masa & 0,080 & $-0,081$ & $-0,175$ & $-0,260$ & $-0,133$ \\
\hline
\end{tabular}

Ket; $*=$ menunjukkan nyata taraf kepercayaan 0,05

** = menujukkan nyata taraf kepercayaan 0,01

Pada Tabel 8 memperlihatkan bahwa peranan penyuluh perikanan sangat berhubungan erat sampai tahap mencoba dan berhubungan erat pada tahap menerapkan para responden terkait inovasi yang dianjurkan yaitu budidaya ikan lele sangkuriang pada kolam terpal. Sedangkan peranan ketua kelompok sangat berhubungnha erat sampai tahap menilai inovasi yang dianjurkan bagi para responden. Peranan dinas perikanan dan peranan media massa kurang berhubungan erat dengan tingkat adopsi budidaya ikan lele sangkuriang pada kolam terpal.

Nilai korelasi hubungan antara. karakteristik inovasi dengan tingkat adopsi pada responden seperti pada Tabel 9.

Table 9. Nilai Korelasi Karakteristik Inovasi dengan Tingkat Adopsi

\begin{tabular}{|l|c|c|c|c|c|}
\hline \multicolumn{1}{|c|}{ TK. Adopsi } & Sadar & Minat & Menilai & Mencoba & Menerapkan \\
\hline$>$ Karakteristik Inovasi & & & & & \\
\hline$>$ Keuntungan relatif & $-0,090$ & $\mathbf{- 0 , 4 9 5 * *}$ & $-0,122$ & 0,073 & 0,25 \\
\hline$>$ Kompleksibitas & $-0,309$ & $\mathbf{- 0 , 6 5 5 * *}$ & $-0,173$ & 0,143 & 0,173 \\
\hline$>$ Dapat Dicoba & $-0,343$ & $\mathbf{- 0 , 5 9 6 * *}$ & $\mathbf{- 0 , 4 5 9 * *}$ & 0,230 & 0,226 \\
\hline$>$ Bisa diamati & $\mathbf{- 0 , 3 7 7} *$ & $\mathbf{- 0 , 5 8 5 * *}$ & $\mathbf{0 , 4 4 1 *}$ & 0,233 & 0,049 \\
\hline
\end{tabular}

Ket; * = menunjukkan nyata taraf kepercayaan 0,05

$* *=$ menunjukkan nyata pada taraf nyata 0,01 
Hasil uji korelasi antara karakteristik inovasi dengan tingkat adopsi memperlihatkan bahwa karakteristik inovasi yaitu adanya keuntungan relatif budifdaya ikan lele asngkuriang dibandingkan inovasi lainnya (budidaya pertanian), keselarasan inovasi dengan kondisi lingkungan responden berhubungan sangat erat sampai pada tahap minat responden pada inovasi tersebut. Budidaya ikan lele sangkuriang yang dianggap tidak rumit diterapkan/dipraktekan oleh responden sangat berhubungan erat bagi responden untuk berminat dan sampai menghitung untung rugi dari inovasi tersebut (tahap minat). Sedangkan budidaya ikan lele sangkuriang yang dianggap mudah dicoba pada lahan responden berhubungan erat pada tahap responden menyadari bahwa budidaya ikan lele sangkuriang dapat dilakukan di lahan responden dan sangat berhubungan erat bagi responden untuk berminat dan sampai menghitung untung rugi dari inovasi tersebut (tahap minat). Budidaya ikan lele sangkuriang dengan karakteristik yang mudah diamati hasilnya oleh responden berhubungan erat pada tahap minat pada responden dan berhubungan sangat erat pada tahap mencoba inovasi tersebut pada lahan responden. Namun demikian berdasarkan hasil analisis ciri inovasi teknologi budidaya ikan lele sangkuriang pada kolam terpal dengan ciri yang mudah dan cepat diamati yang bedrhubungan sangat erat kecepatan adopsi sampai tahap mencoba, sedangkan ciri inovasi lainnya baru sampai rata-rata pada tahap mminat.

Secara umum hasil uji korelasi antara variabel yang dinalisis yaitu anatara karakteristik internal responden, karakteristik eksternal responden, serta karakteristik inovasi dengan tingkat adopsi inovasi yang meliputi tahap sadar, tahap minat, tahap menlai, tahap mencoba dan tahap menerapkan seperti pada Gambar 2.

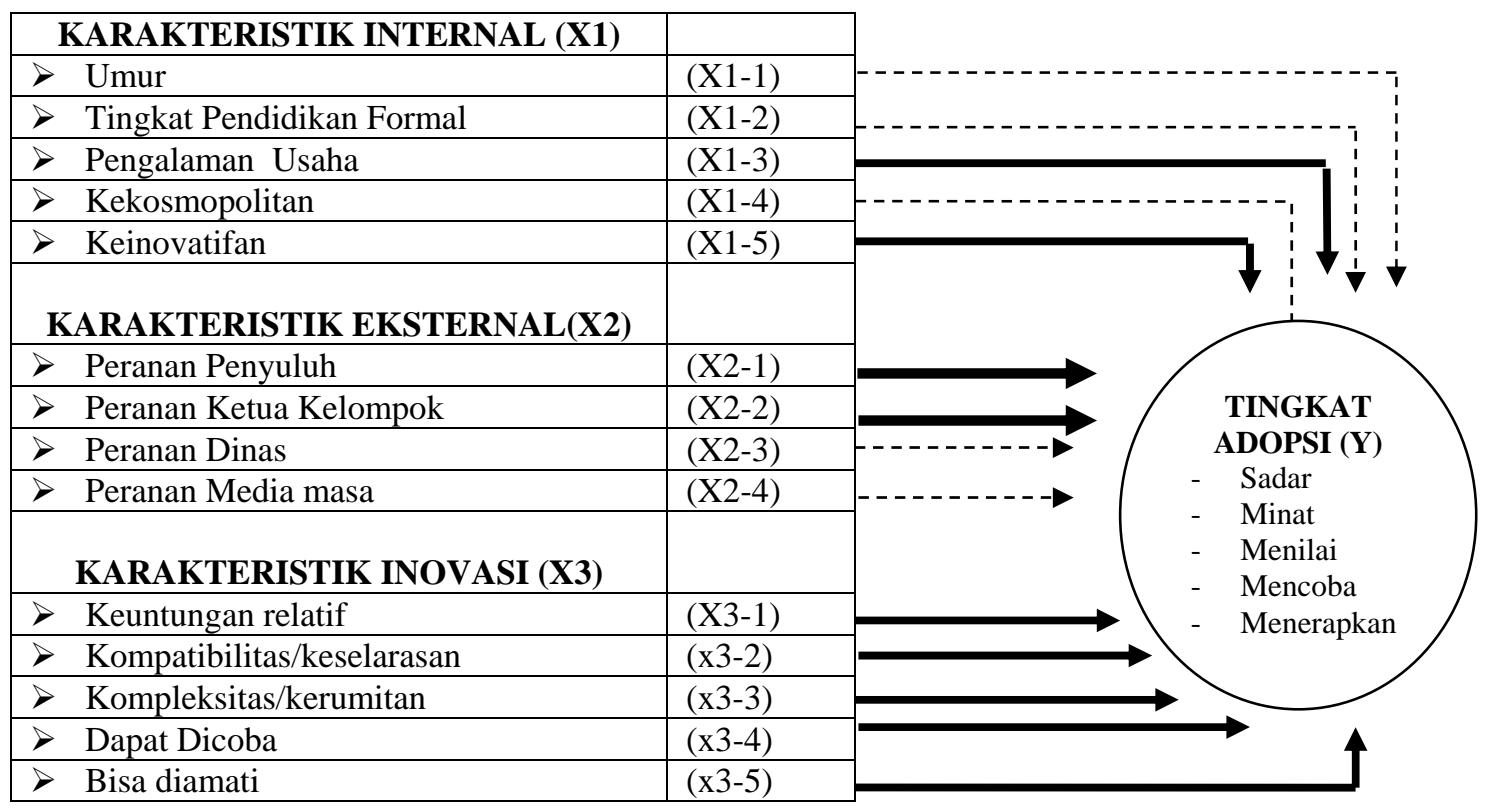

Keterangan

Memiliki hubungan yang erat 
Pada Gambar 2 menunjukkan bahwa pada karakteristik internal responden yang memiliki hubungan yang erat dengan kecepatan tingkat adopsi budidaya ikan lele sangkuriang pada kolam terpal adalah pengalaman usaha responden yaitu pada tahap adopsi mencoba dan tingkat keinovatifan responden yaitu pada tahap menerapkan.

Karakteristik ekternal responden yang memiliki hubungan yang erat dengan kecepatan adopsi inovasi budidaya ikan lele sangkuriang pada kolam terpal adalah peranan penyuluh perikanan yaitu sampai tahap mencoba dan menerapkan inovasi teknologi, dan peranan ketua kelompok erat hubungannya sampai tahap menilai inovasi yang didifusikan. Sedangkan peranan Dinas perikanan kabupaten Lebak dan peranan Media masa tidak kuat hubungannya dengan tingkat kecepatan adopsi inovasi teknologi inovasi budidaya ikan lele sangkuriang pada kolam terpal.

Karakteristik inovasi dalam hal ini budidaya ikan lele sangkuriang pada kolam terpal (keuntungan relatif, keselarasan inovasi dengan kondisi dan buddaya masyarakat, kemudahan inovasi bagi responden, dapat dicobanya inovasi dalam sekala kecil serta inovasi tersebutr dapat dan cepat diamati hasilnya oleh responden berhubungan erat dan sangat erat dengan tingkat kecepatan adopsi responden.

\section{Analisis Kecepatan Adopsi Inovasi}

Analisis kecepatan adopsi inovadin dari ke 30 responden yang mendapat difusi inovasi teknologi pemebesaran ikan lele sangkuriang dari pertama kali inovasi tersebut disampaikan seperti pada Gambar 3
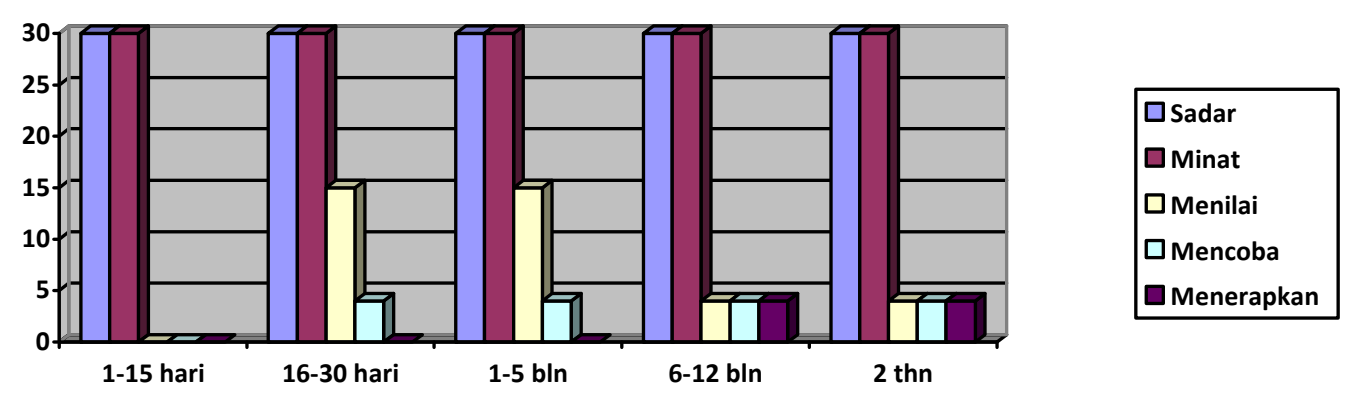

Grafik Tingkat Kecepatan Adopsi

Pada garifik memperlihatkan bawa berdasarkan hasil analisis dari mulai inovasi teknologi pembesaran ikan lele sangkuriang di suluhkan sampai hasil kuisioner pada hari ke 15, ke 30 responden telah menyadari bahwa di daerahnya dapat dilakukan usaha budidaya ikan lele sangkuriang pada kolam terpal, hal tersebut terlihat pada respon pada fasilitaor saat dilakukan kegiatan penyuluhan. Analisis sampai hari ke 30 puluh atau satu bulan setelah inovasi tersebut didifusikan ke 30 orang peserta juga mulai berminat, dengan ikut sertanya ke 30 orang tersebut pada setiap pertemuan, sampai mengikuti kegiatan 
percontohan usaha yang dikelola oleh kelompok. Namun demikian baru sebanyak 15 orang yang mulai bertanya tentang biaya dan pendapatan dalam usaha yang dilakukan, serta terdapat 4 orang yang sudah mulai mencoba di lahan rumahnya.

Kondisi responden setelah 6 bulan sampai satu tahun hanya 4 orang yang konsisten dalam adopsi mencoba dan sekaligus melakukan usaha di kolam pribadinya, sedangkan yang lainnya baru sampai tahap minat, yaitu hanya mengikuti kegiatan usaha yang dijalankan kelompok. Setelah waktu 2 tahun sejak inovasi tersebut didifusikan hanya 4 orang yang melakukan usaha atau hanya $13,3 \%$ yang mengadopsi sampai menerapkan.

\section{KESIMPULAN DAN SARAN}

\section{KESIMPULAN}

1. Pengalaman usaha responden memiliki hubungan yang erat dengan kecepatan tingkat adopsi budidaya ikan lele sangkuriang kolam terpal yaitu pada tahap adopsi mencoba.

2. Tingkat keinovatifan responden berhubungan erat dengan tingkat adopsi yaitu pada tahap menerapkan.

3. Peranan penyuluh perikanan berhubungan erat dengan tigkat adopsi pembudidaya ikan lele yaitu sampai tahap mencoba dan menerapkan inovasi teknologi.

4. Peranan ketua kelompok erat hubungannya sampai tahap menilai inovasi yang didifusikan.

5. Peranan Dinas perikanan kabupaten Lebak dan peranan Media masa tidak kuat hubungannya dengan tingkat kecepatan adopsi inovasi teknologi inovasi budidaya ikan lele sangkuriang pada kolam terpal.

6. Karakteristik inovasi dalam hal ini budidaya ikan lele sangkuriang pada kolam terpal (keuntungan relatif, keselarasan inovasi dengan kondisi dan buddaya masyarakat, kemudahan inovasi bagi responden, dapat dicobanya inovasi dalam sekala kecil serta inovasi tersebutr dapat dan cepat diamati hasilnya oleh responden berhubungan erat dan sangat erat dengan tingkat kecepatan adopsi responden.

\section{SARAN}

1. Penentuan materi penyuluhan perikanan yang bersifat tekinis harus memperhatikan karakteristik internal responden, karakteristik ekternal responden, serta karakteristik inovasi sebagai matari penyuluhan perikanan yang akan disampaikan.

2. Analisis kebutuhan materi penyuluhan perikanan sangat penting, untuk itu sebelum merlakukan penyuluhan kegiatan tersebut harus dilakukan.

3. Karakteristik inovasi perikanan yang akan dijadikan sebagai materi penyuluhan perikanan, harus dilakukan analisis terlebh dahulu kepada sasaran penyuuhan sebelum didfusikan. 
DAFTAR PUSTAKA

Anonimous, 2003. Membentuk Pola Perilaku Manusia

Pembangunan. IPB Press.

Rogers, E.M. \& FF Shoemaker, 1987. Memasyarakatkan Ide-Ide baru. Disarikan oleh Abdillah hanafi. Surabaya: Usaha Nasional.

Sunarru Samsi Hariadi, 2011. Dinamika Kelompok. Teori dan Aplikasi untuk Analisis
Keberhasilan Kelompok Tani sebagai Unit Belajar, Kerjasama, Produksi, dan Bisnis. Peneribit UGM Yogjakarta.

Van den Ban \& HS Hawkins, 1998. Penyuluhan Pertanian. Agnes D Herdiastuti, penerjemah. Terjemahan dari Agricuktural Extention (Second Edition). Kanasius Yogyakarta. 